\title{
SANSEVIERIA HYACINTHOIDES (L.) DRUCE: A REVIEW OF ITS BOTANY, MEDICINAL USES, PHYTOCHEMISTRY, AND BIOLOGICAL ACTIVITIES
}

\author{
ALFRED MAROYI* \\ Department of Botany, Medicinal Plants and Economic Development Research Centre, University of Fort Hare, Private Bag X1314, Alice \\ 5700, South Africa. Email: amaroyi@ufh.ac.za
}

Received: 28 June 2019, Revised and Accepted: 29 July 2019

\begin{abstract}
Sansevieria hyacinthoides is a succulent perennial herb widely used as herbal medicine. This study is aimed at providing a critical review of the botany, biological activities, phytochemistry, and medicinal uses of $S$. hyacinthoides. Documented information on the botany, biological activities, medicinal uses, and phytochemistry of S. hyacinthoides was collected from several online sources which included BMC, Scopus, SciFinder, Google Scholar, Science Direct, Elsevier, PubMed and Web of Science. Additional information on the botany, biological activities, phytochemistry, and medicinal uses of $S$. hyacinthoides was gathered from pre-electronic sources such as book chapters, books, journal articles, and scientific publications obtained from the university library. This study showed that the leaf sap, leaves, rhizomes, roots, and whole plant parts of $S$. hyacinthoides are used as ethnoveterinary medicine, magical purposes, to dilate birth canal and as herbal medicine for fever, respiratory problems, intestinal parasites, worms, rheumatism, swellings, skin infections, sexually transmitted infections, hemorrhoids, toothache, diarrhea, stomach problems, insect and snake bites, earache, and infections. Phytochemical analyses revealed that the leaves, rhizomes, and roots are characterized by alkaloids, flavonoids, and steroids. Pharmacological research revealed that $S$. hyacinthoides crude extracts have anthelmintic, antibacterial, antifungal, and antioxidant activities. Future ethnopharmacological research should focus on carrying out detailed phytochemical, pharmacological, and toxicological studies.
\end{abstract}

Keywords: Asparagaceae, Ethnopharmacology, Herbal medicine, Indigenous pharmacopeia, Sansevieria hyacinthoides.

(C) 2019 The Authors. Published by Innovare Academic Sciences Pvt Ltd. This is an open access article under the CC BY license (http://creativecommons. org/licenses/by/4. 0/) DOI: http://dx.doi.org/10.22159/ajpcr.2019.v12i9.34721

\section{INTRODUCTION}

Sansevieria hyacinthoides (L.) Druce is a member of the Asparagaceae family [1], a classification system that is in agreement with the Angiosperm Phylogeny Group [2]. S. hyacinthoides has also been placed within Agavaceae, Convallariaceae, Dracaenaceae, Liliaceae, and Ruscaceae families [3-18]. According to Plants of the World Online [19], S. hyacinthoides is a synonym of Dracaena hyacinthoides (L.) Mabb. However, according to the plant list, created and managed by the Royal Botanic Gardens (UK) and the Missouri Botanical Gardens (USA), $S$. hyacinthoides is a valid and accepted name [20]. These observed taxonomical problems associated with $S$. hyacinthoides corroborate observations made by Dauncey et al. [21] that there are ambiguities and errors in the use of scientific names mainly because of using older names or an out of date taxonomy. Dauncey et al. [21] argued that there is need to use scientific plant names appropriately and unambiguously as a means of ensuring scientific integrity. Therefore, in this study, the name $S$. hyacinthoides and family Asparagaceae have been adopted and will be used throughout the manuscript. $S$. hyacinthoides is native to east, central, and southern Africa, but the species has been introduced to several other countries as an ornamental and fiber crop [18,22]. In Bangladesh and South Africa, S. hyacinthoides is grown in home gardens as an ornamental, medicinal, and spiritual plant [23-28]. The leaves and roots of $S$. hyacinthoides are marketed as herbal medicines in the Eastern Cape and KwaZulu-Natal provinces in South Africa [29,30]. $S$. hyacinthoides is also one of the important medicinal plants in South Africa, included in the book "medicinal plants of South Africa," a photographic guide to the most commonly used plant medicines in the country, including their botany, main traditional uses, and active ingredients [31]. Research by Van Wyk [32] showed that the leaves and roots of $S$. hyacinthoides have commercial potential as herbal medicines for ear infections, hemorrhoids, and skin ulcers in South Africa. It is within this context that this review was undertaken aimed at reviewing the botany, medicinal uses, phytochemical, and biological activities of $S$. hyacinthoides so as to provide baseline data required in evaluating the therapeutic potential of the species.

\section{BOTANICAL PROFILE OF S. HYACINTHOIDES}

The genus Sansevieria Thunb. is in honor of an Italian Pietro Antonio Sanseverino, Count of Chiaromonte (1724-1771) in whose garden the plant was growing [33]. The specific name hyacinthoides means resembling a hyacinth [33]. The name $S$. hyacinthoides is associated with the following synonyms: Aletris guineensis (L.) Jacq, A. hyacinthoides var. guineensis L., Aloe guineensis L., A. hyacinthoides L., A. hyacinthoides var. guineensis L., Cordyline guineensis (Willd.) Britton, S. angustiflora Lindb., S. grandis var. zuluensis N.E. Br., $S$. guineensis (L.) Willd., S. metallica Gérôme and Labroy, and $S$. thyrsiflora (Petagna) Thunb. $[4,6,9,10,18]$. S. hyacinthoides is native to Kenya, Malawi, Mozambique, Namibia, South Africa, Tanzania, and Zambia and Zimbabwe [4-7,9,10,12,18], but the species has been introduced in America, Asia, Australia, and Europe as an ornamental and fiber crop [18,22,34-36]. S. hyacinthoides has been recorded in all six Dutch Caribbean islands, and it is regarded as a weed $[37,38]$. S. hyacinthoides was introduced to Florida around 1800 , and the species has been categorized as an invasive weed since 1951and currently regarded as one of the six "worst plant invaders" in Florida [39,40]. S. hyacinthoides is included in the Global Compendium of Weeds $[40,41]$ and currently naturalized in Anguilla, Australia, Bahamas, Barbados, Bermuda, Cayman Islands, Cuba, Florida, Jamaica, Mexico, Puerto Rico, the US Virgin Islands, and West Indies $[22,40-46]$. Where $S$. hyacinthoides is naturalized, the species has been recorded in a variety of habitats which include disturbed areas, roadsides, secondary forests, coastal forest, and Shrubland in dry, arid, and semiarid ecosystems [22,40,45].

S. hyacinthoides is a succulent, robust, evergreen, stemless, and perennial herb which can grow up to $60 \mathrm{~cm}$ in height [9]. S. hyacinthoides has fleshy creeping rhizomes that are sturdy, fibrous, and bright orange in color. The leaves are erect, rigid, loosely clustered, fibrous, flat, and arising from a horizontal underground rhizome. The leaves are lanceolate or narrowly elliptic in shape, the apex acute or obtuse, the blade leathery and dull green but mottled transversely with numerous more or less 
obscure pale green bands and the margins with a fine reddish line. The inflorescence is a many-flowered raceme, with stalkless flowers that are white, cream-colored or greenish-white to pale mauve in color. The flowers form small berry-like fruits, which are green at first, gradually becoming yellow when they ripen.

\section{MEDICINAL USES OF S. HYACINTHOIDES}

The leaf sap, leaves, rhizomes, roots, and whole plant parts of $S$. hyacinthoides are used as ethnoveterinary medicine, magical purposes, to dilate birth canal and as herbal medicine for fever, respiratory problems, intestinal parasites, worms, rheumatism, swellings, skin infections, sexually transmitted infections, hemorrhoids, toothache, diarrhea, stomach problems, insect and snake bites, earache, and infections (Table 1 and Fig. 1). In Bangladesh, the fruits of $S$. hyacinthoides are mixed with Aconitum napellus L. and Mucuna pruriens (L.) DC. as an herbal medicine for urinary problems [46].

\section{PHYTOCHEMICAL COMPOSITION OF S. HYACINTHOIDES}

Gamboa-Angulo et al. [100] identified steroids 25S-ruscogenin and $1 \beta, 3 \beta$-dihydroxy-5,16-pregnadien-20-one from the leaves of $S$. hyacinthoides while Khare [8] identified alkaloids aconitic acid and Sansevieria from the leaves and roots of the species (Table 2). Sultana et al. [25] identified a flavonoid isokaemferide and steroids $\beta$-sitosterol and daucosterol from the rhizomes of $S$. hyacinthoides (Table 2). Van Wyk et al. [31] argued that the value of $S$. hyacinthoides in treating hemorrhoids is due to the presence of various sapogenins, particularly 25S-ruscogenin.

\section{BIOLOGICAL ACTIVITIES OF S. HYACINTHOIDES}

The following biological activities have been reported from the leaf and root extracts and compounds isolated from $S$. hyacinthoides: Anthelmintic [54], antibacterial [25,54,57,69,94,95,101], antifungal $[25,57,94,95]$, and antioxidant [102-105] activities.

Table 1: Medicinal uses of Sansevieria hyacinthoides

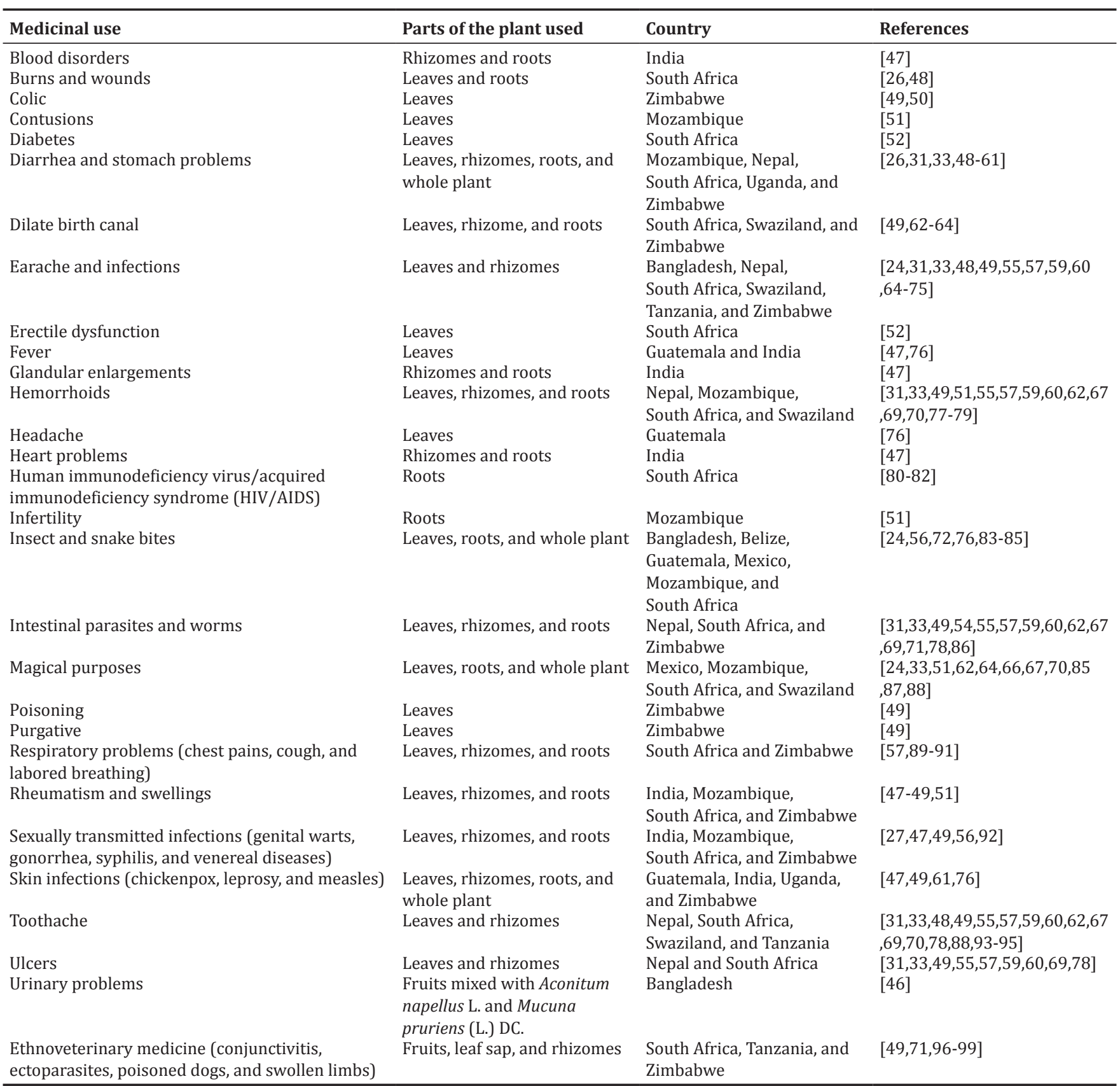




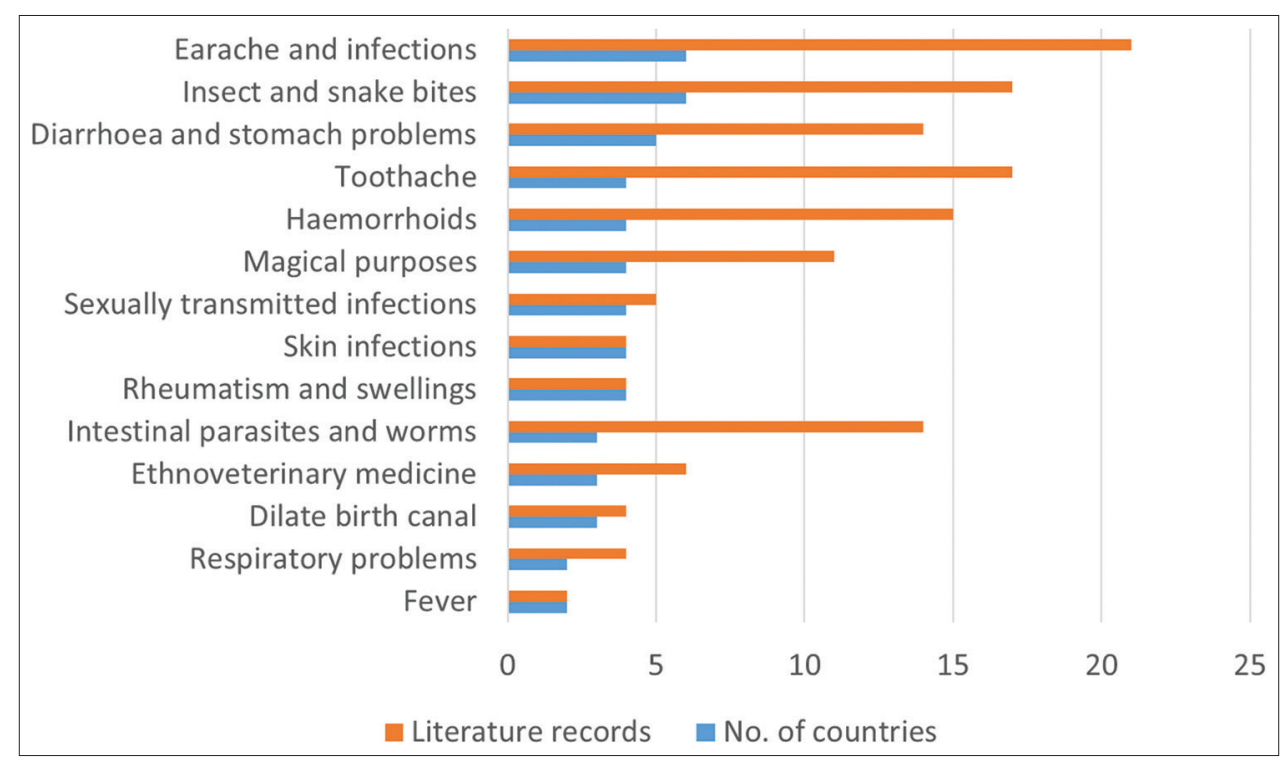

Fig. 1: Ethnomedicinal applications of Sansevieria hyacinthoides

Table 2: Phytochemical composition of Sansevieria hyacinthoides

\begin{tabular}{|c|c|c|}
\hline Phytochemical composition & $\begin{array}{l}\text { Plant } \\
\text { parts }\end{array}$ & References \\
\hline \multicolumn{3}{|l|}{ Alkaloid } \\
\hline Aconitic acid & Leaves & [8] \\
\hline Sansevieria & Roots & [8] \\
\hline \multicolumn{3}{|l|}{ Flavonoid } \\
\hline Isokaemferide & Rhizome & {$[25]$} \\
\hline \multicolumn{3}{|l|}{ Steroids } \\
\hline 25S-ruscogenin & Leaves & [100] \\
\hline $1 \beta, 3 \beta$-dihydroxy-5,16-pregnadien-20-one & Leaves & {$[100]$} \\
\hline$\beta$-sitosterol & Rhizome & [25] \\
\hline Daucosterol & Rhizome & [25] \\
\hline
\end{tabular}

\section{Anthelmintic activities}

McGaw et al. [54] evaluated anthelmintic activities of hexane, ethanol, and waterleaf extracts of $S$. hyacinthoides on the mortality and reproductive ability of the free-living nematode Caenorhabditis elegans in two different assays. Water extract exhibited activities at a concentration of $1 \mathrm{mg} / \mathrm{ml}$ and $2 \mathrm{mg} / \mathrm{ml}$ after the 7 days incubation period [54].

\section{Antibacterial activities}

McGaw et al. [54] evaluated the antibacterial activities of aqueous, ethanol, and hexane leaf extracts of $S$. hyacinthoides against Bacillus subtilis, Escherichia coli, Klebsiella pneumoniae, and Staphylococcus aureus using the disc-diffusion and microdilution assays, with neomycin $(5 \mu \mathrm{g})$ as the positive control. Water extract exhibited activities with minimum inhibitory concentration (MIC) value of $6.3 \mathrm{mg} / \mathrm{mL}$ against B. subtilis [54]. Case [69] evaluated antibacterial activities of $50 \%$ methanol and aqueous leaf extracts of S. hyacinthoides against S. aureus, Pseudomonas aeruginosa, and Mycobacterium smegmatis using a disc diffusion assay with ciprofloxacin as a positive control. The $50 \%$ methanol extract exhibited weak activities against $S$. aureus and M. smegmatis with the zone of inhibition of $1 \mathrm{~mm}$ against $9 \mathrm{~mm}$ exhibited by the control [69]. Sultana et al. [25] evaluated antibacterial activities of methanol and n-hexane rhizome extracts of $S$. hyacinthoides as well as compounds isokaemferide, $\beta$-sitosterol, and daucosterol isolated from the species against Bacillus cereus, $B$. subtilis, E. coli, P. aeruginosa, S. aureus, and Salmonella typhi using the disc diffusion method with kanamycin as a positive control. The crude extracts were active against all tested pathogens with the exception of B. cereus with MIC values ranging from $7.0 \mathrm{mg} / \mathrm{ml}$ to
$16.0 \mathrm{mg} / \mathrm{ml}$. The compounds were active against B. subtilis, S. aureus, and Salmonella typhi with MIC values ranging from $7.0 \mathrm{mg} / \mathrm{ml}$ to $9.0 \mathrm{mg} / \mathrm{ml}$ [25]. Nielsen et al. [57] evaluated antibacterial activities of the methanol leaf and rhizome extracts of $S$. hyacinthoides against Citrobacter spp., S. aureus, E. coli, K. pneumoniae, P. aeruginosa, and M. smegmatis using the microbroth dilution method with gentamicin and ciprofloxacin as positive controls. The extracts exhibited weak activities with MIC values ranging from $312.5 \mu \mathrm{g} / \mathrm{ml}$ to $>2500 \mu \mathrm{g} /$ $\mathrm{ml}$ which were much higher than MIC values of $0.3 \mu \mathrm{g} / \mathrm{ml}$ to 19.5 $\mu \mathrm{g} / \mathrm{ml}$ exhibited by the controls [57]. York et al. [101] assessed the antibacterial properties of aqueous and dichloromethane-methanol (1:1) leaf extracts of $S$. hyacinthoides against K. pneumoniae, Moraxella catarrhalis, M. smegmatis, and S. aureus using microdilution assay with ciprofloxacin as the positive control. The extract showed activities with MIC values ranging from $1.7 \mathrm{mg} / \mathrm{ml}$ to $>16.0 \mathrm{mg} / \mathrm{ml}$ [101]. Akhalwaya [94] and Akhalwaya et al. [95] evaluated antibacterial activities of aqueous and dichloromethane: methanol (1:1) leaf and rhizome extracts of $S$. hyacinthoides against Streptococcus mutans, Streptococcus sanguis, Lactobacillus acidophilus, Lactobacillus casei, Porphyromonas gingivalis, and Fusobacterium nucleatum using the microtiter plate dilution assay with ciprofloxacin $(0.1 \mathrm{mg} / \mathrm{mL})$ as a positive control. The extracts exhibited activities with MIC values ranging from $0.3 \mathrm{mg} / \mathrm{mL}$ to $>8.0 \mathrm{mg} / \mathrm{mL}[94,95]$.

\section{Antifungal activities}

Sultana et al. [25] evaluated antifungal activities of methanol and n-hexane rhizome extracts of $S$. hyacinthoides as well as compounds isokaemferide, $\beta$-sitosterol, and daucosterol isolated from the species against Candida albicans using the disc diffusion method with kanamycin as a positive control. The methanol and n-hexane extracts were active with MIC values of $11.0 \mathrm{mg} / \mathrm{ml}$ and $12.0 \mathrm{mg} / \mathrm{ml}$, respectively, and compound isokaemferide was active with MIC value of $9.0 \mathrm{mg} / \mathrm{ml}$ [25]. Nielsen et al. [57] evaluated antifungal activities of methanol leaf and rhizome extracts of $S$. hyacinthoides against $C$. albicans and Microsporum audouinii using the microbroth dilution method with nystatin as a positive control. The rhizome and leaf extracts exhibited MIC values of $156.3 \mu \mathrm{g} / \mathrm{ml}$ and $312.5 \mu \mathrm{g} / \mathrm{ml}$, respectively, against both fungi species in comparison to MIC value of $19.5 \mu \mathrm{g} / \mathrm{ml}$ exhibited by the control [57]. Akhalwaya [94] and Akhalwaya et al. [95] evaluated antifungal activities of aqueous and dichloromethane:methanol (1:1) leaf and rhizome extracts of $S$. hyacinthoides against $C$. albicans, Candida glabrata, and Candida krusei using the microtiter plate dilution assay with amphotericin B $(0.01 \mathrm{mg} / \mathrm{mL})$ as a positive control. The extracts exhibited activities with MIC values ranging from $0.5 \mathrm{mg} / \mathrm{mL}$ to $>8.0 \mathrm{mg} / \mathrm{mL}[94,95]$. 


\section{Antioxidant activities}

Aliero et al. [102] evaluated the antioxidant activities of acetone and methanol leaf and root extracts of $S$. hyacinthoides using the 1,1-diphenyl2-picrylhydrazyl free radical (DPPH) free radical scavenging assay. The leaf extracts showed activities at $1 \mathrm{mg} / \mathrm{ml}$ exhibiting over $80 \%$ DPPH activity, while acetone and methanol extracts from the roots at $0.75 \mathrm{mg} / \mathrm{ml}$ exhibited $91.4 \%$ and $92.8 \%$ DPPH scavenging activities, respectively [102]. Tkachenko et al. [103] evaluated the antioxidant activities of leaf extracts of $S$. hyacinthoides by assessing their in vitro effects against protein damage in equine erythrocytes using the carbonyl derivatives content of protein oxidative modification (OMP) assay. The extract efficiently inhibited the formation of ketonic derivatives of OMP showing potential in protecting the protein groups and reducing the protein carbonyl content [103]. Tkachenko et al. [104] evaluated the antioxidant activities of leaf extracts of $S$. hyacinthoides by assessing their in vitro effects against protein damage in equine erythrocytes using the OMP assay. The extracts reduced the concentration of ketonic derivatives of OMP when compared to untreated erythrocytes by $13.4 \%$ [104]. Similarly, Tkachenko et al. [105] evaluated the antioxidant activities of leaf extracts of $S$. hyacinthoides by assessing the level of 2-thiobarbituric acid reactive substances (TBARS) as biomarkers of lipid peroxidation in equine erythrocyte suspension induced by treatment of the leaf extracts. The leaf extracts resulted in a significant increase of $29.7 \%$ of TBARS concentration in erythrocytes. These results suggest that $S$. hyacinthoides has a promising antioxidant and prooxidant potential.

\section{CONCLUSION}

The present review summarizes the botany, medicinal uses, phytochemistry, and pharmacological properties $S$. hyacinthoides. From a chemical, pharmacological, and toxicological point of view, $S$. hyacinthoides has not received any major emphasis. At present, there is not yet enough data on ethnopharmacological evaluations on the species that can be correlated with its medicinal applications. Therefore, detailed phytochemical, pharmacological, and toxicological studies of $S$. hyacinthoides are recommended.

\section{ACKNOWLEDGMENTS}

The author would like to express his gratitude to the National Research Foundation, South Africa and Govan Mbeki Research and Development Centre, University of Fort Hare for financial support to conduct this study.

\section{AUTHOR'S CONTRIBUTIONS}

The author declares that this work was done by the author named in this article.

\section{CONFLICTS OF INTEREST}

The author declares that there are no conflicts of interest regarding the publication of this paper.

\section{REFERENCES}

1. Takawira-Nyenya R, Mucina L, Cardinal-Mcteague WM, Thiele KR. Sansevieria (Asparagaceae, Nolinoideae) is a herbaceous clade within Dracaena: Inference from non-coding plastid and nuclear DNA sequence data. Phytotaxa 2018;376:254-76.

2. Angiosperm Phylogeny Group. An update of the angiosperm phylogeny group classification for the orders and families of flowering plants: APG III. Bot J Linn Soc 2009;161:105-21.

3. Koller AL, Rost TL. Leaf anatomy in sansevieria (Agavaceae). Am J Bot 1988;75:615-33.

4. Mbugua PK, Moore DM. Taxonomic Studies of the Genus Sansevieria (Dracaenaceae). In: Van der Maesen LJ, Van der Burgt M, Van Medenbach de Rooy JM, editors. The biodiversity of African plants. Dordrecht: Springer; 1996. p. 489-92.

5. Takawira R, Nordal I. The genus Sansevieria (family Dracaenaceae) in Zimbabwe. Acta Hortic 2001;572:189-98.

6. Germishuizen G, Meyer NL. Plants of Southern Africa: An Annotated
Checklist. Pretoria: Strelitzia 14. Pretoria: National Botanical Institute; 2003.

7. Takawira-Nyenya R. A taxonomic study of the genus Sansevieria (Dracaenaceae) in Zimbabwe. In: Ghazanfar SA, Beentje JJ, editors. Taxonomy and Ecology of African Plants, their Conservation and Sustainable Use. London: Royal Botanic Gardens, Kew; 2006. p. 61-71.

8. Khare CP. Indian Medicinal Plants: An Illustrated Dictionary. New York: Spinger; 2007.

9. Mwachala G, Mbugua PK. Dracaenaceae. In: Beentje HJ, Ghazanfar SA, editors. Flora of Tropical East Africa 1. London: Royal Botanic Gardens, Kew; 2007. p. 10-41.

10. La Croix I. Dracaenaceae. In: Timberlake JR, Martins ES, editors. Flora Zambesiaca. Vol. 13. London: Royal Botanic Gardens, Kew; 2010. p. 13-35.

11. Patil DA, Rai RM. The floral anatomy and taxonomy of the genus Sansevieria. Natl J Life Sci 2010;7:149-52.

12. Manning JC, Goldblatt P. Plants of the Greater Cape Floristic Region 1: The Core Cape Flora. Cape Town: Strelitzia 29, South African National Biodiversity Institute; 2012.

13. Menale B, De Luca P, Del Guacchio E. A plea to restore Petagna's authorship for the genus Sansevieria, nom. Cons. (Liliaceae). Taxon 2013;62:387-90.

14. ThiedeJ, Campbell-Barker PT. Sansevieria burdettii (Asparagaceael Dracaenaceae): Its history, introduction and distribution, with new localities. Bradleya 2015;33:27-33.

15. Singhurst JR, Mink JN, Holmes WC. Sansevieria hyacinthoides (Agavaceae) naturalized in Texas. Phytoneuron 2016;24:1-3.

16. Philip D, Kaleena PK, Valivittan K. Antioxidant potential of Sansevieria roxburghiana Schult. And Schult. F. Asian J Pharm Clin Res 2012;5:166-9.

17. Prakash VE. Terpenoids as source of anti-inflammatory compounds. Asian J Pharm Clin Res 2017;10:68-76.

18. Newton LE. Sansevieria ruscaceae. In: Eggli U, Nyffeler R, editors. Monocotyledons: Illustrated Handbook of Succulent Plants. Berlin: Springe; 2018. p. 1-37.

19. Plants of the World Online. Sansevieria hyacinthoides (L.) Druce; 2019. Available from: http://www.plantsoftheworldonline.org/taxon/ urn: 1sid:ipni.org: names:540510-1. [Last accessed on 2019 Apr 19].

20. The Plant List. Sansevieria hyacinthoides (L.) Druce; 2019. Available from: http://www.theplantlist.org/tpl1.1/record/kew-287144. [Last accessed on 2019 Apr 09].

21. Dauncey EA, Irving J, Allkin R, Robinson N. Common mistakes when using plant names and how to avoid them. Eur J Integr Med 2016;8:597-601.

22. Van der Burg WJ, De Freitas J, Debrot AO, Lotz LA. Naturalised and Invasive Alien Plant Species in the Caribbean Netherlands: Status, Distribution, Threats, Priorities and Recommendations. Wageningen: Plant Research International; 2012.

23. Ghani A. Medicinal Plants of Bangladesh with Chemical Constituents and Uses. Dhaka: Asiatic Society of Bangladesh; 2003.

24. Zobolo AM, Mkabela QN. Traditional knowledge transfer of activities practised by Zulu women to manage medicinal and food plant gardens. Afr J Range Forage Sci 2006;23:77-80.

25. Sultana N, Rahman MM, Ahmed S, Akter S, Haque MM, ParveenS, et al. Antimicrobial compounds from the rhizomes of Sansevieria hyacinthoides. Bangladesh J Sci Ind Res 2011;46:329-32.

26. Maroyi A, Mosina GK. Medicinal plants and traditional practices in peri-urban domestic gardens of the Limpopo Province, South Africa. Indian J Ind Knowl 2014; 13:665-72.

27. Semenya SS, Potgieter MJ. Medicinal plants cultivated in bapedi traditional healers homegardens, Limpopo Province, South Africa. Afr J Tradit Complement Altern Med 2014;11:126-32.

28. Mosina GKE, Maroyi A, Potgieter MJ. Useful plants grown and maintained in domestic gardens of the Capricorn district, Limpopo Province, South Africa. Ethno Med 2015;9:43-58.

29. Cunningham AB. African Medicinal Plants: Setting Priorities at the Interface between Conservation and Primary Health Care. Paris: People and Plants Working Paper 1, UNESCO; 1993.

30. Dold AP, Cocks ML. The trade in medicinal plants in the Eastern Cape province, South Africa. S Afr J Sci 2002;98:589-97.

31. Van Wyk BE, Van Oudtshoorn B, Gericke N. Medicinal Plants of South Africa. Pretoria: Briza Publications; 2013.

32. Van Wyk BE. The potential of South African plants in the development of new medicinal products. S Afr J Bot 2011;77:812-29.

33. Mothogoane MS. Sansevieria hyacinthoides (L.) Druce; 2015. Available from: http://www.pza.sanbi.org/sansevieria-hyacinthoides. 
[Last Accessed on 2019 Apr 04]

34. Correll DS, Correll HB. Flora of the Bahama Archipelago. Vaduz: J Cramer; 1982.

35. Dahlgren RM, Clifford HT, Yeo PF. The Families of Monocotyledons: Structure, Evolution and Taxonomy. New York: Springer Verlag; 1985.

36. Berry MV. Geographic origins of medicinal plants in Montserrat, West Indies, pre-1632 to present. Southeast Geogr 2003;43:75-88.

37. Howard RA. Flora of the Lesser Antilles (Leeward and Windward Islands). Jamaica Plain: Arnold Arboretum, Harvard University; 1989.

38. Berkowitz BN. Home Gardenscapes for the Promotion of Ecological and Cultural Plant Diversity on Sint Eustatius, Dutch Caribbean. MA Dissertation. Ohio: Miami University; 2017.

39. Cochrane CB. Antibacterial and antifungal screening of Florida's exotic invasive plant species. In: Jones DT, Gamble BW, editors. Proceedings of the 1998 Joint Symposium: Florida Exotic Pest Plant Council and the Florida Native Plant Society of South Florida Water Management District. Florida: West Palm Beach; 1999. p. 205-16.

40. Langeland KA, Cherry HM, McCormick CM, Craddock BK. Identification and Biology of Nonnative Plants in Florida's Natural Areas. Florida: University of Florida, IFAS Communication Services; 2008

41. Randall RP. A Global Compendium of Weeds. Perth: Australia: Department of Agriculture and Food Western Australia; 2012.

42. Proctor GR. Flora of the Cayman Islands. London: Royal Botanical Gardens, Kew; 1984.

43. Broome R, Sabir K, Carrington S. Plants of the Eastern Caribbean. Barbados: University of the West Indies; 2007.

44. Acevedo-Rodríguez P, Strong MT. Catalogue of the Seed Plants of the West Indies. Vol. 98. Washington DC: Smithsonian Contributions to Botany; 2012

45. González-Torres LR, Rankin R, Palmarola A. Invasive plants in Cuba. Bissea. Bol Conserv Plant Jardin Bot Natl 2012;6:1-140.

46. Rahmatullah M, Azam NK, Malek I, Nasrin D, Jamal F, Rahman A, et al. An ethnomedicinal survey among the Marakh sect of the Garo tribe of Mymensingh district, Bangladesh. Int J PharmTech Res 2012;4:141-9.

47. Chopra RN, Nayar SL, Chopra IC. Glossary of Indian Medicinal Plants. New Delhi: CSIR, 1956

48. Sagbo IJ, Mbeng WO. Plants used for cosmetics in the Eastern Cape Province of South Africa: A case study of skin care. Pharmacogn Rev 2018;12:139-56.

49. Takawira-NyenyaR, Stedje B. Ethnobotanical studies in the genus Sansevieria Thunb. (Asparagaceae) in Zimbabwe. Ethnobot Res Appl 2011;9:421-43

50. Maroyi A. Traditional use of medicinal plants in south-central Zimbabwe: Review and perspectives. J Ethnobiol Ethnomed 2013;9:31.

51. Ribeiro A, Romeiras MM, Tavares J, Faria MT. Ethnobotanical survey in Canhane village, district of Massingir, Mozambique: Medicinal plants and traditional knowledge. J Ethnobiol Ethnomed 2010;6:33

52. Chauke MA, Shai LJ, Mogale MA, Tshisikhawe MP, Mokgotho MP. Medicinal plant use of villagers in the Mopani district, Limpopo province, South Africa. Afr J Tradit Complement Altern Med 2015;12:9-26

53. Pujol J. Natur Africa: The Herbalist Handbook. Durban: Jean Pujol Natural Healers Foundation; 1990.

54. McGaw LJ, Jäger AK, Van Staden J. Antibacterial, anthelmintic and anti-amoebic activity in South African medicinal plants. J Ethnopharmacol 2000;72:247-63.

55. Van Wyk BE, Gericke N. People's Plants: A Guide to Useful Plants of Southern Africa. Pretoria: Briza Publications; 2007.

56. Bruschi P, Morganti M, Mancini M, Signorini MA. Traditional healers and laypeople: A qualitative and quantitative approach to local knowledge on medicinal plants in Muda (Mozambique). J Ethnopharmacol 2011;138:543-63.

57. Nielsen TR, Kuete V, Jager AK, Meyer JJ, Lall N. Antimicrobial activity of selected South African medicinal plants. BMC Complement Altern Med 2012;12:74

58. Semenya SS, Maroyi A. Medicinal plants used by the bapedi traditional healers to treat diarrhoea in the Limpopo Province, South Africa. J Ethnopharmacol 2012;144:395-401.

59. Lall N, Kishore N. Are plants used for skin care in South Africa fully explored? J Ethnopharmacol 2014;153:61-84.

60. Singh S. Ethno botanical study of some wild herb species Parsa district forest of Nepal. J Pharmacogn Phytochem 2015;4:32-40

61. Shehu MW, Bello I, Abdulkadir N, Shehu A, Jamil SE, Waziri SA. Utilization of medicinal plants used in the management of HIV/AIDS opportunistic infections in Njeru sub-county, Buikwe District, Uganda. MOJ Bioequiv Availab 2018;5:66-72.

62. Watt JM, Breyer-Brandwijk MG. The Medicinal and Poisonous Plants of Southern and Eastern Africa. London: E. and S. Livingstone; 1962

63. Chigora P, Masocha R, Mutenheri F. The role of indigenous medicinal knowledge (IMK) in the treatment of ailments in rural Zimbabwe: The case of Mutirikwi communal lands. J Sustain Dev Afr 2007;9:26-43.

64. Amusan OO. Ethical and environmental issues in bioprospecting for drugs through traditional medicine: The case for Swaziland. Afr J Pl Sci Biotechnol 2008;2:1-9.

65. Bryant AR. Zulu Medicine and Medicine-men. Cape Town: Struik; 1966

66. Roberts M. (1990), Indigenous Healing Plants. South Africa: Southern Book, Halfway House.

67. Hutchings A, Scott AH, Lewis G, Cunningham AB. Zulu Medicinal Plants: An Inventory. Pietermaritzburg: University of Natal Press; 1996.

68. De Andrade VM. Siyezwangabantu: Listening to the Approaches of a Group of Traditional Healers Towards Hearing Impairment. MA Dissertation. Johannesburg: University of the Wiwatersrand; 2000

69. Case O. An assessment of Medicinal Hemp Plant Extracts as Natural Antibiotic and Immune Modulation Phytotherapies. MSc Thesis. Cape Town: University of the Western Cape; 2005.

70. Long C. Swaziland's Flora: Siswati Names and uses. Mbabane: Swaziland National Trust Commission; 2005. Available from: http:// www.sntc.org.sz/index.asp. [Last accessed on 2019 Apr 04].

71. Cocks ML, Dold AP. Cultural significance of biodiversity: The role of medicinal plants in urban African cultural practices in the Eastern Cape, South Africa. J Ethnobiol 2006;26:60-81.

72. Kabir MH, Hasan N, Rahman MM, Rahman MA, Khan JA, Hoque NT, et al. A survey of medicinal plants used by the deb barma clan of the Tripura tribe of Moulvi Bazar district, Bangladesh. J Ethnobiol Ethnomed 2014;10:19.

73. Shaheen ME, Syef MA, Saha SS, Islam MS, Hossain MD, Sujan MA, et al. Medicinal plants used by the folk and traditional medicinal practitioners in two villages of Khakiachora and khasia palli in Sylhet district, Bangladesh. Adv Nat Appl Sci 2010;5:9-19.

74. York T, de Wet H, van Vuuren SF. Plants used for treating respiratory infections in rural Maputaland, KwaZulu-natal, South Africa. J Ethnopharmacol 2011;135:696-710.

75. Dyubeni L, Buwa LV. An ethnobotanical study of plants used for the treatment of ear, nose and throat (ENT) infections in nkonkobe municipality, South Africa. J Med Plant Res 2012;6:2721-6.

76. Kufer J, Förther H, Pöll E, Heinrich M. Historical and modern medicinal plant uses. the example of the ch'orti' maya and ladinos in Eastern Guatemala. J Pharm Pharmacol 2005;57:1127-52.

77. Rankoana SA. The use of Indigenous Knowledge for Primary Health Care Among the Northern Sotho in the Limpopo Province. PhD Thesis. Sovenga: University of Limpopo; 2012.

78. Wintola OA, Afolayan AJ. An inventory of indigenous plants used as anthelmintics in Amathole district municipality of the Eastern Cape Province, South Africa. Afr J Tradit Complement Alter Med 2015;12:112-21.

79. Rankoana SA. Curative care through administration of plant-derived medicines in Sekhukhune district municipality of Limpopo Province, South Africa. Afr J Tradit Complement Alter Med 2016;13:47-51.

80. Semenya SS, Potgieter MJ, Erasmus LJ. Indigenous plant species used by Bapedi healers to treat sexually transmitted infections: Their distribution, harvesting, conservation and threats. S Afr J Bot 2013;87:66-75

81. Semenya SS, Potgieter MJ, Erasmus LJ. Bapedi phytomedicine and their use in the treatment of sexually transmitted infections in Limpopo Province, South Africa. Afr J Pharm Pharmacol 2013;7:250-62.

82. Semenya SS, Potgieter MJ, Erasmus LJ. Ethnobotanical survey of medicinal plants used by bapedi traditional healers to manage HIV/ AIDS in the Limpopo Province, South Africa. J Med Plant Res 2013;7:434-41.

83. Saravia-Otten P, Hernández R, Gutiérrez JM, Mérida M, Cáceres A. Evaluation of the neutralizing capacity of plant extracts of popular use in Guatemala as antidotes for poisoning by the bite of the snake Bothrops asper? Cien Tecn Salud 2015;2:25-37.

84. Giovannini P, Howes MR. Medicinal plants used to treat snakebite in Central America: Review and assessment of scientific evidence. J Ethnopharmacol 2017;199:240-56.

85. Estrada-Castillón E, Villarreal-Quintanilla JÁ, Rodríguez-Salinas MM, Encinas-Domínguez JA, González-Rodríguez H, Figueroa GR, et al. Ethnobotanical survey of useful species in Bustamante, Nuevo León, 
Mexico. Hum Ecol 2018;46:117-32

86. Cock IE, Selesho MI, Van Vuuren SF. A review of the traditional use of southern African medicinal plants for the treatment of selected parasite infections affecting humans. J Ethnopharmacol 2018;220:250-64

87. Cunningham AB. An Investigation of the Herbal Medicine Trade in KwaZulu-Natal. Pietermaritzburg: Institute of Natural Resources Investigational Report 29, University of Natal; 1988.

88. Corrigan BM, Van Wyk B-E, Geldenhuys CJ, Jardine JM. Ethnobotanical Plant uses in the KwaNibela Peninsula, St Lucia, South Africa. S Afr J Bot 2011;77:346-59.

89. Semenya SS, Maroyi A. Ethnobotanical survey of plants used by Bapedi traditional healers to treat tuberculosis and its opportunistic infections in the Limpopo Province, South Africa. S Afr J Bot 2019; 122:401-21.

90. Semenya SS, Maroyi A. Source of plants used by traditional healers for respiratory infections and related symptoms in the Limpopo Province. J Biol Sci 2019;19:101-21.

91. Semenya SS, Maroyi A. Source, harvesting, conservation status, threats and management of indigenous plant used for respiratory infections and related symptoms in the Limpopo province, South Africa. Biodiversitas 2019;20:790-811.

92. Asong JA, Ndhlovu PT, Khosana NS, Aremu AO, Otang-Mbeng W. Medicinal plants used for skin-related diseases among the Batswanas in Ngaka Modiri Molema district municipality, South Africa. S Afr J Bot 2019. Doi.org/10.1016/j.sajb.2019.05.002.

93. Hutchings A. Zulu Medicinal Plants. Pietermaritzburg: University of Natal Press; 1996.

94. Akhalwaya S. The Antimicrobial Investigation of Indigenous South African Medicinal Plants against Oral Pathogens. MSc Dissertation. Johannesburg: University of the Witwatersrand; 2017.

95. Akhalwaya S, Van Vuuren S, Patel M. An in vitro investigation of indigenous South African medicinal plants used to treat oral infections. J Ethnopharmacol 2018;210:359-71.

96. Bizimana N. Traditional Veterinary Practice in Africa. Eschborn:
Deutsche Gesellschaftfür Technische Zusammenarbeit GmbH; 1994.

97. Dold AP, Cocks ML. Traditional veterinary medicine in the Alice district of the Eastern Cape Province, South Africa. S Afr J Sci 2001;97:375-9.

98. McGaw LJ, Eloff JN. Ethnoveterinary use of southern African plants and scientific evaluation of their medicinal properties. J Ethnopharmacol 2008;119:559-74.

99. Nyahangare ET, Mvumi BM, Mutibvu T. Ethnoveterinary plants and practices used for ecto-parasite control in semi-arid smallholder farming areas of Zimbabwe. J Ethnobiol Ethnomed 2015;11:30.

100. Gamboa-Angulo MM, Reyes-López J, Peña-Rodríguez LM. A natural pregnane from Sansevieria hyacinthoides. Phytochem 1996;43:1079-81.

101. York T, van Vuuren SF, de Wet H. An antimicrobial evaluation of plants used for the treatment of respiratory infections in rural Maputaland, KwaZulu-natal, South Africa. J Ethnopharmacol 2012;144:118-27.

102. Aliero AA, Jimoh FO, Afolayan AJ. Antioxidant and antibacterial properties of Sansevieria hyacinthoides. Int J Pure Appl Sci 2008;2:103-10.

103. Tkachenko H, Buyun L, Maryniuk M, Osadowski Z. A comparative study of effect of various Sansevieria Thunb. Leaf extracts on the lipid peroxidation in the equine erythrocyte suspension. Agrobio Improv Nutr Health Life Qual 2018;5:69-81.

104. Tkachenko H, Buyun L, Pażontka-Lipiński P, Witaszek M, Maryniuk M, Osadowski Z. Extract Obtained from Leaves of Sansevieria hyacinthoides (L.) Druce Reduced Oxidative Damage of Proteins in Equine Erythrocytes. Medicinal Herbs: from Past Experience to New Technologies. Pospelov SV, editor. Poltava: Proceedings of Sixth International Scientific and Practical Conference Dec., 26-27; 2017. p. 206-11.

105. Tkachenko $H$, Buyun $L$, Pażontka-Lipiński $P$ Witaszek $M$, Osadowski Z. In vitro protective effect of extracts obtained from various Sansevieria species against oxidative damage of proteins in equine erythrocytes. Słupskie Prace Biol 2017;14:247-65. 